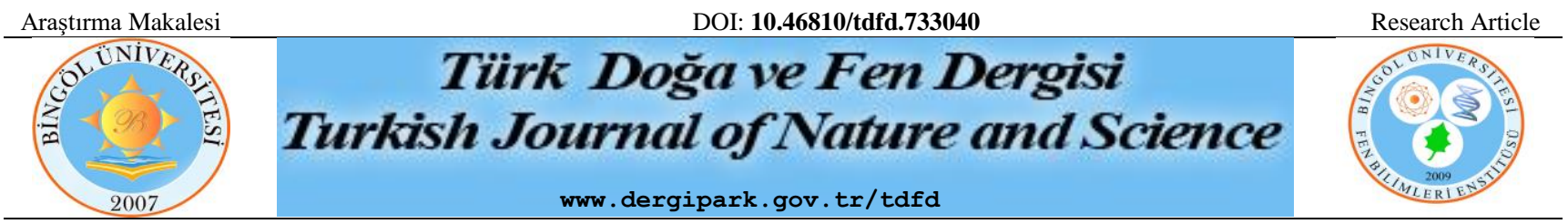

\title{
Bingöl Koşullarında Karabuğday Çeşitlerinde Ekim Zamanının Ot Verimi ve Kalitesi Üzerine Etkileri
}

\author{
Remziye ALKAY ${ }^{1}$, Kağan KÖKTEN ${ }^{2 *}$ \\ ${ }^{1}$ Bingöl Üniversitesi, Fen Bilimleri Enstitüsü, Tarla Bitkileri ABD, 12000 Bingöl, Türkiye \\ ${ }^{2}$ Bingöl Üniversitesi, Ziraat Fakültesi, Tarla Bitkileri Bölümü, 12000 Bingöl, Türkiye \\ Remziye ALKAY ORCID No: 0000-0002-0714-7633 \\ Kağan KÖKTEN ORCID No: 0000-0001-5403-5629 \\ *Sorumlu yazar: e-posta: kkokten@bingol.edu.tr
}

(Alınış: 17.03.2020, Kabul: 19.05.2020, Online Yayınlanma: 18.06.2020)

\begin{abstract}
Anahtar
Kelimeler

Karabuğday,

Bingöl,

Ekim zaman1,

Verim

Öz: Bu çalışma; Bingöl koşullarında karabuğday çeşitlerinde farklı ekim zamanlarının ot verimi ve kalitesine etkisinin belirlemesi amacıyla, 2018 yılında Bingöl Üniversitesi Tarımsal Uygulama ve Araştırma Alanında yürütülmüştür. Denemede bitkisel materyal olarak Aktaş ve Güneş çeşitleri kullanılmış ve tesadüf blokları faktöriyel deneme desenine göre dört tekerrürlü olarak yürütülmüştür. Araştırmada, karabuğday çeşitlerinde dört farklı ekim zamanı (25 Nisan, 5 Mayıs, 15 Mayıs ve 25 Mayıs) olacak şekilde ekim yapılmıştır. İncelenen özellikler arasında; yeşil ot verimi, kuru ot verimi, ham protein oranı, ham protein verimi, Asit deterjanda çözünmeyen lif (ADF), Nötr deterjanda çözünmeyen lif (NDF), Sindirilebilir Kuru Madde (SKM), Kuru Madde Tüketimi (KMT) ve Nispi Yem Değeri (NYD) değerlerinin $\mathrm{p} \leq 0,01$ düzeyinde çok önemli olduğu gözlenmiştir. Elde ettiğimiz sonuçlarda; yeşil ot veriminin $269,75-410,00 \mathrm{~kg} \mathrm{da}^{-1}$, kuru ot veriminin $100,21-142,30 \mathrm{~kg} \mathrm{da}^{-1}$, ham protein oranının \%8,76- 9,88, ham protein veriminin 8,90-12,70 $\mathrm{kg} \mathrm{da}$ ${ }^{1}$, ADF oranının \%40,19-42,04, NDF oranının \%43,51-45,11, SKM oranının \%56,15-57,59, KMT oranının \%2,66-2,77 ve NYD’nin 118,84-123,12 arasında değişim gösterdiği belirlenmiştir. Sonuç olarak; Bingöl ilinde yapılacak karabuğday ekimlerinin Nisan ayının son haftasında yapılması ve mevcut iki çeşit arasında da Güneş çeşidinin tercih edilmesi gerektiği sonucuna varılmıştır.
\end{abstract}

\section{Effects of Sowing Time on Herbage Yield and Quality in Buckwheat Varieties under Bingöl Conditions}

Keywords

Buckwheat,

Bingöl,

Sowing time, Yield

\begin{abstract}
This study was carried out in order to determine the effect of different sowing times on herbage yield and quality in buckwheat varieties under Bingol conditions in Bingol University Agricultural Application and Research Field in 2018. In the experiment, Aktas and Gunes varieties were used as plant materials. The study was carried out in four replications according to randomized block factorial design. In this study, four different sowing times (25 April, 5 May, 15 May and 25 May) were applied to the buckwheat cultivars. In this study, green herbage yield, hay yield, crude protein content, crude protein yield, Acid Detergent Fiber (ADF), Nötral Detergent Fiber (NDF), Dry Digestibility Matter (DDM), Dry Matter Intake (DMI) and Relative Feed Value $(\mathrm{RFV})$ values $(\mathrm{p} \leq 0.01)$ were found to be very important. In the results, we were determined 269.75 $410.00 \mathrm{~kg} \mathrm{da}^{-1}$ of the green herbage yield, $100.21-142.30 \mathrm{~kg} \mathrm{da}^{-1}$ of the hay yield, $8.76-9.88 \%$ of the crude protein content, $8.90-12.70 \mathrm{~kg} \mathrm{da}^{-1}$ of the crude protein yield, $40.19-42.04 \%$ of the ADF ratio, 43.51-45.11\% of the NDF ratio, 56.15-57.59\% of DDM ratio, 2.66-2.77\% of DMI ratio and 118.84123.12 of the RFV. As a result; it has been concluded that buckwheat sowing in Bingol should be done in the last week of April and the Gunes cultivar should be preferred among the two varieties.
\end{abstract}

\section{GİIŞ̧}

Orta Asya kökenli olan karabuğday bitkisi, geçmişi çok eskilere dayanmaktadır. İlk olarak Çin, Kazakistan ve
Ukrayna, ABD ve Avrupa'ya kadar ilerlemiştir. Doğu ve batıya yayılan karabuğday bitkisi soğuk iklim bölgelere kadar aksetmiştir. Ülkemize 2000'li y1llarda giren 
karabuğday bitkisi, Ar-ge üretim çalışmalarında kullanılmıştır $[1,2]$.

Asya kökenli olan karabuğday, tane ve kullanım alanları bakımından tahıl benzeri (pseudocereal) olarak nitelendirilen bir bitkidir [3]. Tahıllar ile hiçbir akrabalığ 1 bulunmayan, tek yıllık bitki olan karabuğday (Fagopyrum esculentum Moench) Polyganeaceae familyasına aittir $[4,5]$.

Karabuğdayın; Gluten içermeyen taneleri nedeniyle çölyak hastalığının tedavisinde önemli bir yeri vardır. Kümes hayvanlarının beslenmesinde taneler yem olarak kullanılırken, sığır beslenmesinde ise yeşil ve kuru ot olarak tüketilmektedir [6,7]. Türkiye'de, yılda iki defa olmak üzere Nisan ve Temmuz aylarında ekimi yapılan sıcak iklim bitkisidir. Kısa vejetasyon süresine sahip olan karabuğday bitkisi, yazları kısa süren soğuk iklim kuşaklarında yetişebilmektedir [8].

Karabuğdayda makineli ve serpme olmak üzere iki farklı ekim şekli uygulanırken, ekim derinliği 2-3 cm arasında tutulmalıdır. Makineli ekimde toprak yapısı, iklim özellikleri ve çeşit özelliklerine göre değişmek üzere 3,5$8 \mathrm{~kg} \mathrm{da}^{-1}$ arasinda tohum kullanılmaktadır. Mibzerle ekimde sıra arası mesafenin 15-20 cm arasında olması tavsiye edilmiştir. Ekimden sonra yaklaşı 85-90 gün sonra hasat olgunluğuna gelen ve bitkide tanelerinin \%75'i kahverengiye dönüştüğü zaman biçerdöverle hasat edilebilir [9].

Uygun ekim zamanı belirlemek tüm bitkilerde yüksek verim ve kaliteyi bulmak açısından çok önemli bir etkendir. Karabuğday bitkisi, dünyada yetiştiriciliği yaygın olarak yapılan ancak ülkemizde denemeler şeklinde üretimi yapılan yeni tanınan bir bitkidir. Ekim zamanı; bölgelere, iklim faktörlerine, toprak yapısına, çeşidine göre değişiklik gösterir.

$\mathrm{Bu}$ çalışma, Bingöl ekolojik koşullarında karabuğday bitkisi için uygun ekim zamanını tespit etmek amacıyla yürütülmüştür.

\section{MATERYAL VE METOT}

$\mathrm{Bu}$ araştırmada bitkisel materyal olarak, Bahri Dağdaş Uluslararası Tarımsal Araştırma Enstitüsü Müdürlüğü tarafindan tescillenen Aktaş ve Güneş karabuğday çeşitleri kullanılmıştır. Araştırma; 2018 yılında Bingöl Üniversitesi Tarımsal Uygulama ve Araştırma Alanında tesadüf blokları faktöriyel deneme desenine göre 4 tekerrürlü olarak kurulmuştur.

Bingöl ili kışları kar yağışlı, sonbahar ve ilkbahar aylarında bol yağış alan, yazları ise sıcak ve kurak karasal bir iklime sahiptir. 2018 yılı yetiştirme döneminde ortalama sicaklığın $\left(20.1{ }^{\circ} \mathrm{C}\right)$ uzun yillar ortalamasının üstünde $\left(17.4{ }^{\circ} \mathrm{C}\right)$, nispi nem (\%45.3) ve toplam yağış $(353.6 \mathrm{~mm})$ miktarının ise uzun yıllar ortalamasının altında (\%48.3 ve $374.1 \mathrm{~mm})$ kaldığı tespit edilmiştir.

Ekim işlemi yapılmadan önce deneme alanından alınan toprak numunesi Bingöl Üniversitesi Ziraat Fakültesi Toprak Bilimi ve Bitki Besleme Bölümünün Toprak Analiz Laboratuvarında analiz edilmiştir. Analiz sonucunda; deneme alanının tınlı toprak yapısına sahip, organik madde yönünden fakir, tuzluluk miktarının az ve $\mathrm{pH}$ değerinin ise hafif asidik seviyede olduğu belirlenmiştir. Potasyum ve kireç oranı düşük olan deneme alanının, fosfor bakımından yeterli seviyede olduğu saptanmıştır.

Deneme alanı, sonbahar ayında yapılan derin sürümden sonra ilkbahar ayında kültivatör ve tapan çekilerek hazırlanmıştır. Parsel alanı $5 \mathrm{~m}$ uzunluğunda, sıra arası mesafenin ise $25 \mathrm{~cm}$ olacak şekilde ve parseller arasında bir sıra boş kalmak şartıyla toplam 5 sıra olacak şekilde el markörü kullanarak sıralar oluşturulmuştur.

Denemede, dekar başına $8 \mathrm{~kg} \mathrm{da}^{-1}$ tohumluk kullanılarak dört farklı zamanda (25 Nisan, 5 Mayıs, 15 Mayıs ve 25 Mayıs) ekim yapılmıştır. Ekim ile birlikte deneme alanına dekar başına $10 \mathrm{~kg} \mathrm{da}^{-1}$ gelecek şekilde DAP gübresi kullanılmıştır.

Ekimin ilk zamanlarında yağmur suyuyla beslenen karabuğday bitkisi, yağmurların kesilmesinden sonra ilk sulama Haziran ayında yapılmıştır. Karabuğday bitkisinin tane dolum aşamasına kadar olan su ihtiyacı yağmurlama sulama ile karşılanmıştır. Bitkilerin gelişmesini engelleyip havasına ve suyuna ortak olan yabanc1 ot kontrolünü ve toprağın havalanmasını sağlamak amacıyla çapa yapıllmıştır.

Denemenin hasadı orak yardımıyla yapılmıştır. Araştırmada yeşil ot, kuru ot ve ham protein verimleri Türk ve ark. [10]'na göre, ham protein oranı AOAC [11]'a göre, ADF ve NDF oranları Van Soest ve ark. [12]'na göre, SKM ve KMT oranları ile NYD ise Morrison [13]'a göre yapılmıştır.

Çalışma sonucunda elde edilen verilere SAS istatistik paket programı yardımıla varyans analizi uygulanmıştır. Varyans analizi sonucunda istatistiki açıdan önemli çıkan etkenlerin ortalamaları LSD testi ile mukayese edilmiştir.

\section{BULGULAR}

\subsection{Yeşil Ot ve Kuru Ot Verimleri (kg/da)}

Farklı zamanlarda ekilen karabuğday çeşitlerinde ekim zamanı ve çeşit açısından hem yeşil ot veriminin hem de kuru ot veriminin istatistiki olarak önemli olduğu, çeşit $x$ ekim zamanı interaksiyonu açısından kuru ot veriminin istatistiki olarak önemli kuru ot veriminin ise önemsiz olduğu saptanmıştır. 
Tablo 1. Farklı zamanlarda ekilen karabuğday çeşitlerinin yeşil ot ve kuru ot verimlerine ait ortalama değerler

\begin{tabular}{|c|c|c|c|c|c|c|}
\hline \multirow{2}{*}{ Ekim Zamanları } & \multicolumn{3}{|c|}{ Yeşil Ot Verimi $\left(\mathrm{kg} \mathrm{da}^{-1}\right)$} & \multicolumn{3}{|c|}{ Kuru Ot Verimi $\left(\mathrm{kg} \mathrm{da}^{-1}\right)$} \\
\hline & Aktaş & Güneş & Ortalama & Aktaş & Güneş & Ortalama \\
\hline 1. Ekim Zamanı & 404,00 & 416,00 & $410,00 \mathrm{~A}^{* *}$ & $144,70 \mathrm{~b}^{* *}$ & $130,28 \mathrm{~b}$ & $137,49 \mathrm{AB}^{* *}$ \\
\hline 2. Ekim Zamanı & 368,15 & 381,30 & 374,72 B & $159,08 \mathrm{a}$ & $93,12 \mathrm{~d}$ & $126,10 \mathrm{~B}$ \\
\hline 3. Ekim Zamanı & 292,80 & 310,10 & $301,45 \mathrm{C}$ & $141,92 \mathrm{~b}$ & $142,68 \mathrm{~b}$ & $142,30 \mathrm{~A}$ \\
\hline 4. Ekim Zamanı & 259,25 & 280,25 & 269,75 D & $87,58 \mathrm{~d}$ & $112,85 \mathrm{c}$ & $100,21 \mathrm{C}$ \\
\hline Ortalama & $331,05 \mathrm{~B}^{*}$ & 346,91 A & & $133,32 \mathrm{~A}^{* *}$ & 119,73 B & \\
\hline
\end{tabular}

Farklı harfle gösterilen değerler arasındaki fark önemlidir $\left({ }^{* *} \mathrm{p} \leq 0,01\right.$ ve $\left.* \mathrm{p} \leq 0,05\right)$.

Tablo 1'deki veriler incelendiğinde, ekim zamanı bakımından $410,00 \mathrm{~kg} \mathrm{da}^{-1}$ ile en yüksek yeşil ot verimi 1.ekim zamanından alınırken, $269,75 \mathrm{~kg} \mathrm{da}^{-1}$ ile en düşük yeşil ot verimi 4. ekim zamanından alınmıştır. Çeşitler açısından baktığımızda Güneş çeşidinin $\left(346,91 \mathrm{~kg} \mathrm{da}^{-1}\right)$, Aktaş çeşidinden $\left(331,05 \mathrm{~kg} \mathrm{da}^{-1}\right)$ daha yüksek yeşil ot verimine sahip olduğu tespit edilmiştir. Karabuğdayda daha önce yapılan çalışmalarda; Isparta koşullarında 2739,33 ve $2760,31 \mathrm{~kg} \mathrm{da}^{-1}$ [14], Karaman koşullarında $374,43-976,38 \mathrm{~kg} \mathrm{da}^{-1}$ [15], Yozgat koşullarında 0,5817,69 t ha $^{-1}$ [16] ve Konya koşullarında 1516,66-3100,00 $\mathrm{kg} \mathrm{da}^{-1}$ [17] olarak elde edilen yeşil ot verimleri, çalışma sonucundan alınan değerlerden yüksek olduğu saptanmıştır.Tabloya bakıldığında, ekim zamanı açısından $142,30 \mathrm{~kg} \mathrm{da}^{-1}$ ile en yüksek kuru ot verimi 3 . ekim zamanında izlenirken, bunu istatistiksel açıdan aynı grupta yer alan 1.ekim zamanı $\left(137,49 \mathrm{~kg} \mathrm{da}^{-1}\right)$ takip etmiştir. En düşük kuru ot verimi $100,21 \mathrm{~kg} \mathrm{da}^{-1}$ ile 4 . ekim zamanında izlenmiştir. Çeşitler açısından incelendiğinde 133,32 $\mathrm{kg} \mathrm{da}^{-1}$ ile Aktaş çeşidinin, 119,73 $\mathrm{kg} \mathrm{da}{ }^{-1}$ ile Güneş çeşidinden daha yüksek kuru ot verimine sahip olduğu belirlenmiştir. Çeşit $\mathrm{x}$ ekim zamanı interaksiyonu bakımından $159,08 \mathrm{~kg} \mathrm{da}^{-1}$ ile en yüksek kuru ot verimi Aktaş çeşidinin 2. ekim zamanından elde edilmiştir. En düşük kuru ot verimi ise $87,58 \mathrm{~kg} \mathrm{da}^{-1}$ ile Aktaş çeşidinin 4. ekim zamanından elde edilirken, bunu 93,12 $\mathrm{kg} \mathrm{da}^{-1}$ ile Güneş çeşidinin 2 . ekim zamanı takip etmiştir. Karabuğdayda daha önce yapılan çalışmalarda kuru ot veriminden elde edilen değerler; Isparta koşullarında 766,13-853,67 kg da ${ }^{-1}$ [14], Yozgat koşullarında 0,14-4,42 $\mathrm{t} \mathrm{ha}^{-1}$ [16] ve Konya koşullarında 481,26-1109,40 $\mathrm{kg} \mathrm{da}^{-1}$ [17] olarak tespit edilmiştir. Yeşil ot ve kuru ot verimlerine ait bulduğumuz veriler ile araştırmacıların elde ettikleri değerler arasındaki farklılık, iklim faktörü, çeşit, toprak yapısı ve farklı hasat zamanlarından kaynaklandığı düşünülmektedir.

\subsection{Ham Protein Oranı (\%) ve Ham Protein Verimi (kg/da)}

Farklı zamanlarda ekilen karabuğday çeşitlerinde ekim zamanı, çeşit ve çeşit $\mathrm{x}$ ekim zamanı interaksiyonu açısından hem ham protein oranının hem de ham protein veriminin istatistiki olarak önemli olduğu saptanmıştır.

Tablo 2'deki değerler incelendiğinde, ekim zamanı açısından en yüksek ham protein oranı $\% 9,88$ ile 2 . ekim zamanında elde edilmiştir. En düşük ham protein oranı $\% 8,76$ ile 4 . ekim zamanında izlenirken, bunu $(\% 8,92)$ 3.ekim zamanı ve $(\% 8,93)$ ile 1 . ekim zamanı takip etmiştir. Çeşitlere baktığımızda ise \%9,39 ile Güneş çeşidinin, \%8,86 ile Aktaş çeşidinden daha yüksek ham protein oranına sahip olduğu görülmüştür. Çeşit x ekim interaksiyonu açısından en yüksek ham protein oranı $\% 10,05$ ile Aktaş çeşidinin 2. ekim zamanında bulunurken, bunu istatistiki açıdan aynı grup içinde yer alan $(\% 9,78)$ Güneş çeşidinin 4. ekim zamanı ve $(\% 9,70)$ Güneş çeşidinin 2. ekim zamanı izlemiştir. En düşük ham protein oranı $\% 7,75$ ile Aktaş çeşidinin 4. ekim zamanında tespit edilmiştir. Karabuğdayda daha önce yapılan çalışmalarda; Kütahya koşullarında \%8,11-9,48 [18] ham protein oranından elde edilen veriler, çalışma sonucundan alınan değerler ile benzerlik gösterdiği saptanmıştır.

Çanakkale koşullarında \%9,28-21,81 [19], Isparta ekolojik koşullarında \%11,37-12,44 [20], Samsun koşullarında \%10,58-12,16 [21], Yozgat koşullarında $\% 10,97-15,81$ [16], Konya koşullarında \%13,56-21,08 [17] ve Isparta koşullarında \%11,40-11,58 [22] olarak bulunmuştur. Elde edilen bu bulgular, çalışma sonucundan alınan verilerden yüksek olduğu belirtilmiştir.

Tablo 2. Farklı zamanlarda ekilen karabuğday çeşitlerinin ham protein oranı ve verimine ait ortalama değerler

\begin{tabular}{|c|c|c|c|c|c|c|}
\hline \multirow{2}{*}{ Ekim Zamanları } & \multicolumn{3}{|c|}{ Ham Protein Oranı (\%) } & \multicolumn{3}{|c|}{ Ham Protein Verimi $\left(\mathrm{kg} \mathrm{da}^{-1}\right)$} \\
\hline & Aktaş & Güneş & Ortalama & Aktaş & Güneş & Ortalama \\
\hline 1. Ekim Zamanı & $8,72 \mathrm{c}^{* *}$ & $9,12 \mathrm{bc}$ & $8,93 \mathrm{~B}^{* *}$ & $12,61 \mathrm{bc}^{* *}$ & $11,89 \mathrm{bc}$ & $12,25 \mathrm{~A}^{* / 2}$ \\
\hline 2. Ekim Zamanı & $10,05 \mathrm{a}$ & $9,70 \mathrm{ab}$ & 9,88 A & $16,00 \mathrm{a}$ & $8,98 \mathrm{~d}$ & $12,49 \mathrm{~A}$ \\
\hline 3. Ekim Zamanı & $8,90 \mathrm{c}$ & $8,95 \mathrm{c}$ & 8,92 B & $12,62 \mathrm{bc}$ & $12,78 \mathrm{~b}$ & $12,70 \mathrm{~A}$ \\
\hline 4. Ekim Zamanı & $7,75 \mathrm{~d}$ & $9,78 \mathrm{ab}$ & 8,76 B & $6,78 \mathrm{e}$ & $11,02 \mathrm{c}$ & 8,90 B \\
\hline Ortalama & $8,86 B^{* *}$ & 9,39 A & & $12,00 \mathrm{~A}^{*}$ & 11,17 B & \\
\hline
\end{tabular}

Farklı harfle gösterilen değerler arasındaki fark önemlidir $(* * \mathrm{p} \leq 0,01$ ve $* \mathrm{p} \leq 0,05)$.

Tabloya baktığımızda, ekim zamanı açısından en yüksek ham protein verimi $12,70 \mathrm{~kg} \mathrm{da}^{-1}$ ile 3 . ekim zamanında izlenirken, bunu istatistiki olarak aynı grupta yer alan $\left(12,49 \mathrm{~kg} \mathrm{da}^{-1}\right) 2$. ekim zamanı ve $\left(12,25 \mathrm{~kg} \mathrm{da}^{-1}\right) 1$. ekim zamanı izlemişstir. En düşük ham protein verimi $8,90 \mathrm{~kg}$ $\mathrm{da}^{-1}$ ile 4. ekim zamanından elde edilmiştir.
Çeşitlere baktı̆̆ımızda ise $\left(12,00 \mathrm{~kg} \mathrm{da}^{-1}\right)$ ile Aktaş çeşidinin, $\left(11,17 \mathrm{~kg} \mathrm{da}^{-1}\right)$ Güneş çeşidinden daha yüksek ham protein verimine sahip olduğu görülmüştür. Çeşit $\mathrm{x}$ ekim zamanı interaksiyonu açısından en yüksek ham protein verimi $16,00 \mathrm{~kg} \mathrm{da}^{-1}$ ile Aktaş çeşidinin 2. ekim zamanında görülürken, en düşük ham protein verimi 
$6,78 \mathrm{~kg} \mathrm{da}^{-1}$ ile Aktaş çeşidinin 4.ekim zamanında tespit edilmiştir.

Karabuğdayda daha önce yapılan çalışmalarda; Konya koşullarında $68,93-164,18 \mathrm{~kg} \mathrm{da}^{-1}$ [17] ham protein veriminden elde edilen bulgular, çalışma sonucundan alınan verilerden yüksek olduğu belirtilmiştir.

Ham protein verimi; ham protein oranı ile kuru ot veriminin çarpılması sonucunda bulunduğundan, farklı ekolojik koşullarda elde edilen kuru ot verimindeki farklılık ham protein veriminde değişiklik göstermesine sebebiyet vermektedir.

\subsection{ADF ve NDF Oranları (\%)}

Farklı zamanlarda ekilen karabuğday çeşitlerinde ekim zamanı, çeşit ve çeşit $\mathrm{x}$ ekim zamanı interaksiyonu açısından hem ADF oranının hem de NDF oranının istatistiki olarak önemli olduğu saptanmıştır.
Tablo 3'deki değerler incelendiğinde, ekim zamanı açısından en yüksek ADF oranı \%42,04 ile 3. ekim zamanında görülürken, bunu istatistiksel olarak aynı grupta yer alan $(\% 41,36)$ ile 4 . ekim zamanı takip etmiştir. En düşük ADF oranı ise $\% 40,19$ ile 2. ekim zamanından elde edilmiştir. Çeşitler açısından değerlendirildiğinde, \%41,70 ile Aktaş çeşidinin, Güneş çeşidinden $(\% 40,36)$ daha yüksek ADF oranına sahip olduğu gözlenmiştir. Çeşit x ekim zamanı interaksiyonu bakımından en yüksek ADF oranı \%42,85 ile Aktaş çeşidinin 1. ekim zamanında görülürken, bunu istatistiki olarak aynı grupta yer alan Güneş çeşidinin 3. ekim zamanı (\%42,20), Aktaş çeşidinin 4. ekim zamanı $(\% 42,02)$ ve 3 . ekim zamanı $(\% 41,88)$ takip etmiştir. En düşük ADF oranı \%38,22 ile Güneş çeşidinin 1.ekim zamanında tespit edilmiştir. Karabuğdayda daha önce yapılan çalışmalarda; Yozgat koşullarında \%33,12-33,51 [16], Konya koşullarında \%25,94-38,11 [17] olarak elde edilen ADF oranları, çalışma sonucundan alınan verilerden düşük olduğu tespit edilmiştir.

Tablo 3. Farklı zamanlarda ekilen karabuğday çeşitlerinin ADF ve NDF oranlarına ait ortalama değerler

\begin{tabular}{|c|c|c|c|c|c|c|}
\hline \multirow{2}{*}{ Ekim Zamanları } & \multicolumn{3}{|c|}{ ADF Oranı (\%) } & \multicolumn{3}{|c|}{ NDF Oranı (\%) } \\
\hline & Aktaş & Güneș & Ortalama & Aktaş & Güneș & Ortalama \\
\hline 1. Ekim Zamanı & $42,85 \mathrm{a}^{* * *}$ & $38,22 \mathrm{~d}$ & $40,54 \mathrm{BC}^{* *}$ & $45,88 \mathrm{a}^{* *}$ & $41,15 \mathrm{~d}$ & $43,51 B^{* *}$ \\
\hline 2. Ekim Zamanı & $40,05 \mathrm{c}$ & $40,32 \mathrm{c}$ & $40,19 \mathrm{C}$ & $44,20 \mathrm{~b}$ & $46,02 \mathrm{a}$ & $45,11 \mathrm{~A}$ \\
\hline 3. Ekim Zamanı & $41,88 \mathrm{ab}$ & $42,20 \mathrm{a}$ & $42,04 \mathrm{~A}$ & $45,65 \mathrm{a}$ & $41,80 \mathrm{~d}$ & 43,72 B \\
\hline 4. Ekim Zamanı & $42,02 \mathrm{a}$ & $40,70 \mathrm{bc}$ & $41,36 \mathrm{AB}$ & $45,65 \mathrm{a}$ & $43,05 \mathrm{c}$ & 44,35 AB \\
\hline Ortalama & $41,70 \mathrm{~A}^{* *}$ & 40,36 B & & $45,34 \mathrm{~A}^{* *}$ & 43,01 B & \\
\hline
\end{tabular}

Farklı harfle gösterilen değerler arasındaki fark önemlidir $(* * \mathrm{p} \leq 0,01$ ve $* \mathrm{p} \leq 0,05)$.

Tabloya bakıldığında, ekim zamanı açısından en yüksek NDF oranı \%45,11 ile 2. ekim zamanında izlenirken, bunu istatistiki olarak aynı grupta yer alan \%44,35 ile 4. ekim zamanı takip etmiştir. En düşük NDF oranı \%43,51 ile 1. ekim zamanından elde edilirken, bunu $(\% 43,72) 3$. ekim takip etmiştir. Çeşitler açısından incelendiğinde, \%45,34 ile Aktaş çeşidinin, \%43,01 Güneş çeşidinden daha yüksek NDF oranına sahip olduğu gözlenmiştir. Çeşit $\mathrm{x}$ ekim zamanı interaksiyonu bakımından en yüksek NDF oranı $\% 46,02$ ile Güneş çeşidinin 2. ekim zamanında görülürken, bunu istatistiksel açıdan aynı grupta yer alan \%45,88 Aktaş çeşidinin 1. ekim zamanı, $\% 45,65$ ile Aktaş çeşidinin 3. ve 4. ekim zamanları takip etmiştir. En düşük NDF oranı \%41,15 ile Güneş çeşidinin 1. ekim zamanında izlenirken, bunu $\% 41,80$ ile yine Güneş çeşidinin 3. ekim zamanı takip etmiştir.
Karabuğdayda daha önce yapılan çalışmalarda; Yozgat koşullarında \%30,45-43,78 [17] NDF oranından elde edilen bu bulgular, çalışma sonucundan aldığımız verilerden düşük olduğu tespit edilmiştir. Yozgat koşullarında \%42,20-52,03 [16] olarak elde edilen NDF oranları, çalışma sonucundan alınan verilerden yüksek olduğu tespit edilmiştir. Bu farklılığın karabuğdaydaki farklı hasat zamanlarından kaynaklandığ düşünülmektedir.

\subsection{SKM ve KMT Oranları (\%)}

Farklı zamanlarda ekilen karabuğday çeşitlerinde ekim zamanı, çeşit ve çeşit $\mathrm{x}$ ekim zamanı interaksiyonu açısından hem SKM oranının hem de KMT oranının istatistiki olarak önemli olduğu saptanmıştır.

Tablo 4. Farklı zamanlarda ekilen karabuğday çeşitlerinin SKM ve KMT oranlarına ait ortalama değerler

\begin{tabular}{|c|c|c|c|c|c|c|}
\hline \multirow{2}{*}{ Ekim Zamanları } & \multicolumn{3}{|c|}{ Sindirilebilir Kuru Madde Oranı (\%) } & \multicolumn{3}{|c|}{ Kuru Madde Tüketimi Oranı (\%) } \\
\hline & Aktaş & Güneş & Ortalama & Aktaş & Güneş & Ortalama \\
\hline 1. Ekim Zamanı & $55,52 \mathrm{~d}^{* *}$ & $59,12 \mathrm{a}$ & $57,32 \mathbf{A B}^{* *}$ & $2,62 d^{* *}$ & $2,92 \mathrm{a}$ & $2,77 \mathrm{~A}^{* *}$ \\
\hline 2. Ekim Zamanı & $57,70 \mathrm{~b}$ & $57,49 \mathrm{~b}$ & $\mathbf{5 7 , 5 9 ~ A ~}$ & $2,72 \mathrm{c}$ & $2,61 \mathrm{~d}$ & $2,66 \mathrm{C}$ \\
\hline 3. Ekim Zamanı & $56,28 \mathrm{~cd}$ & $56,02 \mathrm{~d}$ & $56,15 \mathrm{C}$ & $2,63 \mathrm{~d}$ & $2,87 \mathrm{a}$ & $2,75 \mathrm{AB}$ \\
\hline 4. Ekim Zamanı & $56,16 \mathrm{~d}$ & $57,20 \mathrm{bc}$ & $56,68 \mathrm{BC}$ & $2,63 \mathrm{~d}$ & $2,79 \mathrm{~b}$ & $2,71 \mathrm{BC}$ \\
\hline Ortalama & 56,42 B $^{* *}$ & 57,46 A & & $2,65 B^{* *}$ & $2,80 \mathrm{~A}$ & \\
\hline
\end{tabular}

Farklı harfle gösterilen değerler arasındaki fark önemlidir $(* * \mathrm{p} \leq 0,01$ ve $* \mathrm{p} \leq 0,05)$.

Tablo 4'te görüldüğü gibi ekim zamanı açısından en yüksek SKM oranı \%57,59 ile 2. ekim zamanından elde edilirken, bunu istatistiki olarak aynı grupta yer alan $(\% 57,32)$ 1. ekim zamanı takip etmiştir. En düşük SKM oranı \%56,15 ile 3. ekim zamanından elde edilmiştir Çeşitler açısından değerlendirildiğinde \%57,46 Güneș çeşidinin, \%56,42 ile Aktaş çeşidinden daha yüksek
SKM oranına sahip olduğu gözlenmiştir. Çeşit x ekim zamanı interaksiyonu bakımından en yüksek SKM oranı $\% 59,12$ ile Güneş çeşidinin 1. ekim zamanında tespit edilmiştir. En düşük SKM oranı \% 55,52 Aktaş çeşidinin 1. ekim zamanında bulunurken, bunu \%56,02 Güneș çeşidinin 3. ekim zamanı ve \%56,16 ile Aktaş çeşidinin 4. ekim zamanı takip etmiştir. Karabuğdayda daha önce 
yapılan çalışmalarda SKM oranından elde edilen veriler; Konya koşullarında \%59,20-68,68 [17] olarak elde edilen bu bulgular, çalışma sonucundan alınan verilerden yüksek olduğu tespit edilmiştir.

Tabloya bakıldığında, ekim zamanı açısından incelendiğinde en yüksek KMT oranı \%2,77 ile 1 . ekim zamanında görülürken, bunu istatistiksel bakımından aynı grupta yer alan 3. ekim zamanı $(\% 2,75)$ takip etmiştir. En düşük KMT oranı $\% 2,66$ ile 2. ekim zamanından elde edilmiştir. Çeşitler bakımından incelendiğinde \%2.80 ile Güneş çeşidinin, \%2,65 Aktaş çeşidinden daha yüksek KMT oranına sahip olduğu görülmektedir. Çeşit $\mathrm{x}$ ekim zamanı interaksiyonu bakımından en yüksek KMT oranı \%2,92 ile Güneș çeşidinin 1. ekim zamanında gözlenirken, bunu istatistiki olarak aynı grupta yer alan \%2,87 Güneş çeşidinin 3 . ekim zamanı takip etmiştir. En düşük KMT oranı \%2,61 ile Güneș çeşidinin 2. ekim zamanından elde edilirken, bunu \%2,62 Aktaş çeşidinin 1. ekim zamanı, \%2,63.ile 3. ve 4. ekim zamanı takip etmiştir.

\subsection{NYD (Nispi Yem Değeri)}

Farklı zamanlarda ekilen karabuğday çeşitlerinde ekim zamanı, çeşit ve çeşit $\mathrm{x}$ ekim zamanı interaksiyonu açısından nispi yem değerinin istatistiki olarak önemli olduğu saptanmıştır.

Tablo 5'deki değerler incelendiğinde, en yüksek NYD 123,12 ile 1. ekim zamanında tespit edilmiştir. En düşük NYD ise 118,84 ile 2. ekim zamanında izlenirken, bunu 4. ekim zamanı $(119,04)$ ve 3 . ekim zamanı $(119,72)$ takip etmiştir. Çeşitler bakımından incelendiğinde 124,56 ile Güneş çeşidi, 115,80 ile Aktaş çeşidinden daha yüksek NYD’ne sahip olduğu görülmüştür.

Çeşit x ekim zamanı interaksiyonu bakımından en yüksek NYD değeri 133,65 ile Güneş çeşidinin 1. ekim zamanında izlenirken, en düşük NYD 112,60 ile Aktaş çeşidinin 1.ekim zamanında gözlenmiştir. Karabuğdayda daha önce yapılan çalışmalarda; Konya koşullarında 125,80-209,78 [17] olarak elde edilen nispi yem değeri, çalışma sonucundan alınan verilerden yüksek olduğu tespit edilmiştir.

Tablo 5. Farklı zamanlarda ekilen karabuğday çeșitlerinin nispi yem değerine ait ortalama değerler

\begin{tabular}{|c|c|c|c|}
\hline \multirow[t]{2}{*}{ Ekim Zamanları } & \multicolumn{3}{|c|}{ NYD (Nispi Yem Değeri) } \\
\hline & Aktaş & Güneş & Ortalama \\
\hline 1. Ekim Zamanı & $112,60 \mathrm{e}^{* *}$ & $133,65 \mathrm{a}$ & $123,12 \mathrm{~A}^{* *}$ \\
\hline 2. Ekim Zamanı & $121,48 \mathrm{c}$ & $116,20 \mathrm{~d}$ & 118,84 B \\
\hline 3. Ekim Zamanı & $114,68 \mathrm{de}$ & $124,78 \mathrm{~b}$ & 119,72 B \\
\hline 4. Ekim Zamanı & $114,45 \mathrm{de}$ & $123,62 \mathrm{bc}$ & 119,04 B \\
\hline Ortalama & $115,80 \mathrm{~B}^{* *}$ & $124,56 \mathrm{~A}$ & \\
\hline
\end{tabular}

Farklı harfle gösterilen değerler arasındaki fark önemlidir $(* * \mathrm{p} \leq 0,01$ ve $* \mathrm{p} \leq 0,05)$.

\section{SONUÇ}

Bu çalışma, Bingöl koşullarında karabuğday çeşitlerinde farklı ekim zamanlarının ot verimi ve kalitesine etkilerinin belirlenmesi amaciyla yürütülmüştür. Araştırmada; yeşil ot ve kuru ot verimleri, ham protein oran1, ham protein verimi, ADF, NDF, SKM, KMT ve NYD gibi özelliklere ilişkin değerler incelenmiştir. Çalışmadan elde edilen sonuçları özetlemek gerekirse; yeşil ot verimi, kuru ot verimi, ham protein verimi, sindirilebilir kuru madde, kuru madde tüketimi ve nispi yem değeri açısından birinci ekim zamanının daha iyi sonuçlar verdiği belirlenmiştir. Çeşitler açısından bakıldığında, yeşil ot verimi açısından Aktaş çeşidinin ön plana çıktığı, ancak geriye kalan diğer tüm parametrelerde ise Güneş çeşidinin daha iyi sonuçlar verdiği tespit edilmiştir. Dolayısıyla Bingöl ilinde yapılacak karabuğday ekimlerinin Nisan ayının son haftasında yapılması ve mevcut iki çeşit arasında, Güneş çeşidinin tercih edilmesi gerektiği sonucuna varılmıştır.

\section{Teșekkür}

Bu çalışma Bingöl Üniversitesi, Bilimsel Araştırma Projeleri Koordinasyon Birimi BAP projeleri (Proje No: BAP-ZF.2018.00.013) kapsamında desteklenmiştir. Desteklerinden dolayı Bingöl Üniversitesi BAP Koordinasyon birimine teşekkür ederiz.

\section{KAYNAKLAR}

[1] Dizlek H, Özer MS, İnanç E, Gül H. Karabuğdayın (Fagopyrum esculentum Moench) bileşimi ve gida sanayinde kullanım olanakları. Gida Dergisi. 2009;34(5):317-324.

[2] Kan A. A new plant for Turkey; Buckwheat (Fagopyrum esculentum). Biological Diversity and Conservation. 2014;7(2):154-158.

[3] Yavuz H, Yiğit A, Erenkul O. Farklı ekim sıklıklarının karabuğdayda (Fagopyrum esculentum Moench) verim ve bazı tane kalitesi özelliklerine etkisi. Adnan Menderes Üniversitesi Ziraat Fakültesi Dergisi. 2016;13(2):17-22.

[4] Debnath NR, Rasul MG, Sarker MMH, Rahman $\mathrm{MH}$, Paul AK. Genetic divergence in buckwheat (Fagopyrum esculentum Moench). Int. J. Sustain. Crop Prod. 2008;3(2):60-68.

[5] Acar R. Karabuğdayın (Köşeli Buğday) tarımı. Konya Ticaret Borsas1 Dergisi. 2009;11(31):30-37.

[6] Tahir I, Farooq S. Review article on buckwheat. Buckwheat Newsletter, Fagoprum. 1988;8:33-53.

[7] Wijngaard HH, Arendt EK. Buckwheat. Cereal Chem. 2006;83(4):391-401.

[8] Baburkova M, Valinova J, Moudry J. Influence of nitrogen fertilizer application on yield and chemical composition of buckwheat seeds. Series of Crop Sci. 1999;16:35-40. 
[9] Acar R, Güneş A, Aktaş AH. Karabuğdayla sağlıklı yaşama merhaba. Bahri Dağdaş Uluslararası Tarımsal Araştırma Enstitüsü, Karabuğday Proje Bülteni. 2012;1:1-2.

[10] Türk M, Albayrak S, Yüksel O. Effect of seeding rate on the forage yields and quality in pea cultivars of differing leaf types. Turkish Journal of Field Crops. 2011;16(2):137-141.

[11] AOAC. Official Method of Analysis. 15th. edn. Association of Official Analytical Chemist, Washington, DC. USA. 1990.

[12] Van Soest PJ, Robertson JB, Lewis BA. Methods for dietary fiber, neurtal detergent fiber and nonstarch polysaccharides in relation to animal nutrition. J. Dairy Sci. 1991;74(10):3583-3597.

[13] Morrison JA. Hay and Pasture Management, Chapter 8.Extension Educator, Crop Systems Rockford Extension Center. 2003

[14] Kara N. Yield and mineral nutrition content of buckwheat (Fagopyrum esculentum Moench), the effect of harvest times. Süleyman Demirel Üniversitesi Ziraat Fakültesi Dergisi. 2014;9(1):8594.

[15] Güzelsarı U, Kan Y. Karaman ekolojik şartlarda ikinci ürün olarak yetiştirilen karabuğdayın (Fagpyrum esculentum Moench) argronomik ve kalite özelliklerinin araştırılması. Selçuk Tar Bil Der. 2016;3(2):200-204.

[16] Köksal Ş. Yozgat şartlarda karabuğday (Fagopyrum esculentum Moench) yetiştiriciliği, Yüksek Lisans Tezi, Fen Bilimleri Enstitüsü Tarla Bitkileri Anabilim Dalı, Bozok Üniversitesi, Yozgat, 2017.

[17] Sürmen M, Kara E. Yield and quality features of buckwheat-soybean mixtures in organic agricultural conditions. Turkish Journal of Agriculture - Food Science and Technology. 2017;5(13):1732-1736.

[18] Kaya E, Katar D. Kütahya-Altıntaş koşullarında farklı ekim normları ve zamanlarının karabuğday (Fagopyrum esculentum Moench)'da verim ve bazı verim unsurları üzerine etkisi. 4. Uluslararası Bilimsel Araştırmalar Kongresi. 14-17 Şubat 2019/Yalova. 2019;448-465.

[19] Akçura S. Çanakkale koşullarında karabuğdayda farklı ekim sıklığı ve sıra arası mesafesinin verim ve verim üzerine etkisi, Yüksek Lisans Tezi, Fen Bilimleri Enstitüsü Tarla Bitkileri Anabilim Dalı, Çanakkale Onsekiz Mart Üniversitesi, Çanakkale, 2013.

[20] Kara B, Çelebi FG, Kara N, Atar B. Karabuğday (Fagopyrum esculentum Moench)'da farklı azotlu gübre formlarının etkinliği. Türk Tarım-Gıda Bilim ve Teknoloji Dergisi. 2016;4(6):515-518.

[21] Karafaki R. Samsun koşullarında farklı ekim zamanlarının karabuğdayın (Fagoprum esculentum Moench) önemli tarımsal özellikleri ile bazı kalite kriterlerine etkisi, Yüksek Lisans Tezi, Fen Bilimleri Enstitüsü Tarla Bitkileri Anabilim Dalı, Ondokuz Mayıs Üniversitesi, Samsun, 2017.

[22] Kara N, Gürbüzer G. Investigation of cultivate possibility at different sowing times under natural rainfed conditions of Isparta as spring of buckwheat. Turkish Journal of Agriculture-Food Science and Technology. 2018;6(1):46-50. 